OPEN ACCESS

Edited by:

Arie Trouwborst

Tilburg University, Netherlands

Reviewed by:

Elke Hellinx

KU Leuven, Belgium

Hendrik Schoukens,

Ghent University, Belgium

*Correspondence:

Yaffa Epstein

yaffa.epstein@jur.uu.se

${ }^{t}$ These authors have contributed

equally to this work

Specialty section:

This article was submitted to

Conservation

a section of the journal

Frontiers in Ecology and Evolution

Received: 13 October 2019

Accepted: 30 March 2020

Published: 11 June 2020

Citation:

Epstein Y and Kantinkoski S

(2020) Non-governmental

Enforcement of EU Environmental Law: A Stakeholder Action for Wolf

Protection in Finland.

Front. Ecol. Evol. 8:101.

doi: 10.3389/fevo.2020.00101

\section{Non-governmental Enforcement of EU Environmental Law: A Stakeholder Action for Wolf Protection in Finland}

\author{
Yaffa Epstein ${ }^{1 *+}$ and Sari Kantinkoski2t \\ 'Faculty of Law, Uppsala University, Uppsala, Sweden, ${ }^{2}$ Secretary of Tapiola, Kolho, Finland
}

The Court of Justice of the EU (CJEU) largely sided with a small Finnish nature protection organization, Tapiola, in a recent judgment that interpreted limitations on the deliberate killing of wolves. Tapiola was able to utilize EU law to bring about both national compliance with EU species protection law and a legal decision that will impact the hunting of wolves and other protected species throughout the EU. Using the Finnish wolf controversy as a case study, this article illustrates how law may be used as a tool for environmental protection in the EU, and the interdependence of environmental NGOs and EU institutions in doing so. It also calls attention to the different roles for NGO stakeholders and different potential outcomes in infringement procedures and references for preliminary rulings.

\section{Keywords: Aarhus Convention, NGO, Habitats Directive, environmental law, wolf, Tapiola, Case C-674/17}

\section{INTRODUCTION}

Law is an important means for protecting large carnivores and other wildlife (Trouwborst et al., 2017). Laws give rise to obligations and restrictions for governments, companies and individuals that are enforceable through courts (Chapron et al., 2017). Laws alone cannot protect species, however, they are simply a tool that people can use to do so. To be effective tools, laws must be implemented and enforced.

This article explores an example of people using laws to protect wolves in Finland. In an October 2019 decision, the Court of Justice of the EU (CJEU) largely sided with a small Finnish nature protection organization, Luonnonsuojeluyhdistys Tapiola Pohjois-Savo - Kainuu ry (Tapiola), restrictively interpreting the Habitats Directive in a way that has led the Finnish Supreme Administrative Court to rule in March of 2020 that certain permits allowing wolf hunting in Finland had been illegally granted (Case C-674/17). The CJEU's decision also makes the future authorization of the killing of species protected by EU law more difficult throughout the European Union (EU) (Trouwborst and Fleurke, 2019). Analyzing this concrete example helps clarify the importance and interdependence of stakeholder involvement and EU environmental laws in environmental protection efforts.

The Habitats Directive is the main law that protects terrestrial and aquatic species in the EU (Council Directive 92/42/EEC 1992). Like other EU directives, 
the Habitats Directive sets out certain required results that are determined at the EU level, and Member States must transpose these requirements into national law and ensure that these national laws are enforced. Government actors at different levels - the European Commission, national wildlife authorities, police, public prosecutors, for example-have responsibility for enforcing the Habitats Directive and other environmental laws (Epstein, 2018, p. 496). Non-government actors, particularly environmental NGOs, have increasingly also been entrusted with the power to pursue the implementation and enforcement of these laws (Hofmann, 2019). ${ }^{1}$ The abilities of non-government actors to access environmental information, participate in environmental decision making, and bring litigation when environmental laws are violated have been considered essential prerequisites for these actors to fulfill this function.

In Europe, these three so-called pillars of environmental democracy are provided for in the UNECE Convention on Access to Information, Public Participation in Decision-Making and Access to Justice in Environmental Matters, informally known as the Aarhus Convention (1998). The Member States of the EU are party to this convention, as is the EU itself, which, in short, means that both the EU and its Member States must make it possible for members of the public to access environmental information, participate in environmental decision making, and bring litigation to enforce environmental law.

These procedural environmental rights enable nongovernment actors to take part in the enforcement of EU environmental law, which, it is frequently argued, increases the democratic legitimacy of environmental protection (Gellers and Jeffords, 2018, p. 100). However, public engagement in the enforcement of EU environmental law carries an importance beyond potential benefits to legitimacy. Because the EU has limited resources to investigate and litigate violations of EU law within the Member States, it relies on non-government actors to help bring about compliance (Kelemen, 2011). As argued by academics such as Hofmann (2019) and Eliantonio (2018), and demonstrated by Tapiola, non-governmental actors use EU law, and the EU uses non-governmental actors, to pursue environmental protection in the Member States.

The great majority of cases involving EU law are decided by national courts; in a relatively few cases are questions of EU law decided by EU courts. The two common ways in which Member State violations of EU environmental law reach the CJEU are infringement procedures and references for a preliminary ruling. While NGOs are of course not able to bring either type of case of their own accord, they play an important role in both (Eliantonio, 2018). Because the European Commission, which can bring infringement procedures in the CJEU when a Member State fails to fulfill its obligations under EU law, lacks the administrative apparatus to detect these failures, it is dependent on members of the public to bring them to its attention through its system for receiving complaints (Eliantonio, 2018, p. 756). Most environmental legal actions brought by the European Commission begin with a

\footnotetext{
${ }^{1}$ The idea that the public should have the right to influence decisions that impact the environment is also enshrined in the Finnish constitution at section 20.
}

complaint from an NGO or other member of the public, and these complaints are the main source of information about Member State compliance with EU environmental law (Kramer, 2014, p. 248). The rights of access to information and public participation in environmental decision making enable these stakeholders to provide necessary information about EU law violations to the European Commission.

The European Commission brings only a relatively small number of infringement procedures each year however. Instead, most litigation to enforce EU law occurs in Member States' courts in cases brought by citizens of those states. In environmental law cases, the litigant is often an NGO rather than an individual. The Aarhus Convention and the principle of effectiveness of EU law require that Member States ensure that someone is allowed to bring litigation in national courts to challenge alleged violations of EU environmental law (Case C-243/15) (Epstein, 2018, p. 9); at a minimum, some environmental NGOs must be allowed to bring legal actions (Case C-263/08) (Reichel, 2010). These actions are decided by judges in the Member State courts. However, if the case involves a question of how to interpret EU law that is necessary to decide a case, the court may, and in some cases must, ask the CJEU for a preliminary ruling on how the EU law should be interpreted. When the CJEU makes a preliminary ruling on how to interpret the question of EU law, this interpretation becomes binding throughout the EU. Preliminary rulings are therefore an important way to promote the uniform interpretation of EU law (Eliantonio, 2018).

References for preliminary rulings make up the bulk of the CJEU's case load. In 2018, there were 568 references for a preliminary ruling and 63 direct actions (including infringement procedures) (Court of Justice of the European Union, 2019, p. 141). The European Commission was particularly active in the area of environmental protection, but even so, there were more than twice as many environmental references for a preliminary ruling, 32, as there were direct actions, of which there were 15 (Court of Justice of the European Union, 2019, p. 124). Because of the importance of national courts in applying EU law and facilitating its uniform interpretation, the European Commission has a policy of preferring to pursue infringement procedures in situations where national legal systems prevent stakeholders from seeking recourse in Member State courts (European Commission, 2017). In order for Member State courts to fulfill their role in enforcing EU environmental law, NGOs or other stakeholders must have the right to seek redress for violations of environmental laws, as well as the desire and means to do so.

This article uses legal controversies over the protection of wolves in Finland as a case study to illustrate how stakeholder engagement can lead to the enforcement of EU environmental law in practice. Finland has been forced to defend its wolf management in the CJEU on two occasions. In 2007, it lost an infringement procedure brought by the European Commission and was compelled to improve the legal protection of wolves to comply with EU law. In a second case, this time a 2019 request for a preliminary ruling, the CJEU interpreted EU law largely in agreement with the NGO challenger, which again required Finland to improve protection for wolves. In both these cases, citizen involvement was crucial. Focusing on the second case, this 
article tells the story of how a small group of citizens engaged the Aarhus Convention and EU law to fight for the protection of wolves in Finland. It examines how these stakeholders were able to use the law as a tool for wolf protection, what challenges they faced, what they were able to achieve and what they were not. In doing so, this article illuminates some differences between outcomes that stem from centralized enforcement and those that originate in litigation by non-government actors. It argues that public interest litigation can be an effective tool for species protection in the EU, but is different from and cannot replace centralized enforcement, which also requires citizen involvement in order to be effective.

The authors' engagement with the Tapiola case extends beyond the scope of this article. Kantinkoski is a founding and current board member of Tapiola with a background in biology. She has been involved in Tapiola's advocacy including litigation. Epstein is a researcher in environmental law who has written about legal controversies over large carnivore protection, and previously interviewed board members of Tapiola while writing about this case (Epstein and Chapron, 2018). She has also written about the wide reaching impact of expanded access to justice in environmental matters in the EU on national procedural law and substantive environmental protection (Epstein and Darpö, 2013; Epstein, 2018). In this article, we combine our academic and practical knowledge of EU law and how it has worked in a Member State and at the EU level.

Several recent works have detailed the role of environmental NGOs in enforcing EU environmental law. Eliantonio demonstrated the importance of NGO participation to both infringement proceedings and preliminary rulings. She argues that both processes have shortcomings from the point of view of the NGO (Eliantonio, 2018, p. 763). Hofmann also examined the increasing reliance on NGO litigation in enforcing EU environmental law, and the legal changes that have been required in many Member States, such as Sweden (Case C-263/08), Germany (Case C-137/14, Case C-72/12), Austria (Case C664/15), Slovakia (Case C-243/15), Ireland (Case C-167/17) and others in order to enable this litigation (Hofmann, 2019, p. 3523 ). These articles convincingly demonstrate the importance of NGOs for the application of EU environmental law. A focus on laws and legal outcomes can however obscure the many contingent, human decisions and interactions that occur in every instance of public interest litigation. We therefore use a narrative approach to make less abstract the process of how the law is used to both protect the environment and promote a uniform interpretation of EU law. We expect our results will be useful to those who study European legal integration, particularly in the area of environmental law, as well as to those who are interested in using the law to protect species or other environmental goals.

\section{THE LEGAL AND SOCIAL CONTEXT OF THE FINNISH WOLF CONTROVERSY}

In the 19th and early 20th centuries, wolves were not controversial in Finland, they were simply feared and hated (Ermala, 2003, p. 16-17). Wolves killed not only reindeer and livestock, but also, according to church records from the mid to late 19th century, dozens of children (Linnell et al., 2003, p. 36). Hunts were organized to eradicate the species, and by the beginning of the 20th century had largely been successful (Mykrä et al., 2005, p. 280). While wolves were never completely extirpated from Finland, the population was reduced from an estimated thousand or more at its highest to a few individuals in the 1920s (Ministry of Agriculture and Forestry, 2005; Aspi et al., 2006, p. 1562).

For most of the 20th century, the wolf population hovered between a few and a few dozen individuals (Aspi et al., 2006, p. 1562). ${ }^{2}$ Wolves became a protected species in Finland in 1973. Hunting continued to be allowed in the reindeer management area, approximately the northern $1 / 3$ of Finland, and seasonal hunting was allowed in limited areas outside the reindeer herding area after 1977. Finland joined the EU in 1995 and was eventually compelled to enact stricter protections to comply with the Habitats Directive.

The Habitats Directive requires that EU Member States take measures to protect biodiversity by maintaining or restoring the "favorable conservation status" of certain habitats and species (Council Directive 92/42/EEC 1992, Article 2). For "strictly protected" species, those listed in Annex IV of the Directive, required measures include banning their killing or harming except for very limited and clearly defined purposes when there is no other satisfactory solution and doing so would not be detrimental to maintaining the favorable conservation status of the species (Council Directive 92/42/EEC 1992, Articles 12 \& 16). These purposes, set out in the Directive's Article 16, are (a) to protect wild species and habitats; (b) to prevent serious damage to property; (c) to protect public health or safety or other impetrative reasons of overriding public interest; and (d) for research and education. A fifth provision ["purpose (e)"] does not state a specific purpose, but allows exceptions from the ban to be made under an additional set of restrictive circumstances: "under strictly supervised conditions, on a selective basis and to a limited extent, the taking or keeping of certain specimens of the species ... in limited numbers specified by the competent national authorities."

Additional "protected" species are listed in Annex V of the Directive. Member States may allow hunting of these Annex $\mathrm{V}$ species so long as their favorable conservation status is ensured and certain methods of capture and killing are prohibited (Council Directive 92/42/EEC 1992, Articles 14 and 15). The wolf is listed in Annex IV of the Habitats Directive, meaning hunting must be prohibited. Finland negotiated an exception for wolves in the reindeer management area when it joined the EU, and wolves within this area are listed in Annex V. Wolves are therefore strictly protected in Finland except in the north. While still "protected" in northern Finland, they are in practice killed if they are present in the area (Heikkinen et al., 2019, p. 13).

These protections have been controversial. Despite the fact that no one has been killed by a wolf in Finland since 1881 and numerous significant societal changes make wolf attacks on humans less likely to occur than they were in the 19th century

\footnotetext{
${ }^{2}$ But c.f. Ministry of Agriculture and Forestry, 2005 at 9, noting that some estimates
} claimed there were as many as 300 wolves in Finland during the 1980s. 
(for example children go to school rather than are employed as shepherds), some people continue to fear wolves as a threat to human safety (Linnell et al., 2003). Others dislike wolves because of the real threat they pose to hunting dogs and livestock. Some hostility towards wolves is also attributed to the idea that the EU or Finnish government is forcing policies on or ignoring the needs of people who live in the countryside (Pohja-Mykrä, 2016). In particular, several studies have focused on the strong dislike and illegal hunting of wolves by hunters and others in rural areas (Pohja-Mykrä and Kurki, 2014, p. 72). Finland argued in the Tapiola case that the only solution to improve attitudes toward wolves and protect them from illegal hunting is to allow legal hunting (Case C-674/17, para. 13).

However, while opposition to wolves has been vocal and in many cases resulted in illegal killing of wolves, several studies indicate that a majority of people are not opposed to the presence of wolves in Finland, even in rural areas. Tapiola itself, whose leadership consists of a majority of rural residents, most of whom have hunting permits or close ties to hunting communities, presents a counterexample to the narrative that people who live outside of urban areas and hunters will not tolerate the presence of wolves. A study conducted shortly after Finland's accession to the EU found that 52\% of randomly selected Finnish residents viewed wolves positively, while only $27 \%$ viewed them negatively, though negative opinions were somewhat higher in rural areas (Bisi and Kurki, 2008, p. 21). A survey of stakeholder opinions carried out at the University of Helsinki and published in 2008 found that a majority of the 221 respondents considered that the wolf population size was suitable or should increase; only about $1 / 3$ of respondents would decrease or eliminate wolves, though a majority of hunting association members and agricultural and forestry producers did support a reduction in the wolf population (Bisi and Kurki, 2008, p. 4547). Stakeholders identified as conservationists, unsurprisingly, overwhelmingly supported a population increase (Bisi and Kurki, 2008, p. 45-47).

And although the Finnish wolf debate can be quite heated, it is also worth bearing in mind that many people do not have particularly strong feelings about wolves. A larger survey of 1665 randomly selected Finnish residents carried out in 2016 by the market research firm Taloustutkimus found that while a greater percentage of people would prefer to avoid wolves in the forest (31\%) than would like to encounter them (24\%), the largest group of respondents apparently had no opinion on the topic. A relatively small percentage (22\%) reported fearing wolves. Even in areas with established wolf populations, a minority of livestock or domestic animal owners (47\%) considered wolves to pose a risk to their animals. Of the $75 \%$ of Finns who spend time in the forest picking mushrooms or berries, only about $4 \%$ said this hobby was impacted by wolves, with a somewhat higher $11 \%$ in areas with established wolf populations. About $65 \%$ of respondents were not in favor of the unauthorized killing of wolves in any circumstances (Ministry of Agriculture and Forestry, 2016, p. 12-13). While wolf hunting has been justified by Finnish authorities as a means to reduce hatred or illegal killing of wolves, it should be noted that the majority of Finnish people do not hate wolves or support their illegal killing.

\section{FINNISH WOLF LITIGATION ROUND 1: THE FINNISH ASSOCIATION FOR NATURE CONSERVATION COMPLAINS AND THE EUROPEAN COMMISSION TAKES DIRECT LEGAL ACTION}

At the time of Finland's accession to the EU, its small wolf population was concentrated almost entirely in Eastern Finland (Kojola et al., 2014, p. 282). A working group of Finland's Ministry of Agriculture and Forestry drew up goals for an increase in the wolf population in Western and Central Finland, and for no increase in Eastern Finland or the reindeer management area. Limited hunting continued to be allowed in Eastern Finland to "manage" the wolf population, and wolves continued to be eradicated from the reindeer management area (Ministry of Agriculture and Forestry, 2005, p. 28-29).

The wolf population was slow to make gains in the early years of Finland's participation in the EU. While there is disagreement in the scientific literature as to the numbers of wolves and how to measure them, there are thought to have been about 135 wolves at the time of Finland's 1995 accession, followed by a decline to about 95 individuals by 1998 (Hiedanpää, 2013). In 1997, Finland's largest environmental NGO, The Finnish Association for Nature Conservation (FANC), filed a complaint with the European Commission (March 11, 1997, on file with the authors) arguing that Finland had not taken adequate measures to implement the Habitats Directive, including a failure to protect wolves and other large carnivores. FANC noted that the hunting law did not establish any system of strict protection for Annex IV species, and even classified several of these species, including wolves, bears, lynx, and otters, as game animals that could be hunted. Further, the hunting law did not seek the favorable conservation status of species, nor did it restrict exceptions from strict protection to the limited situations described in the Habitats Directive's Article 16.

While the European Commission has no obligation to follow up on complaints, it chose to do so in this instance. It initiated an "informal dialogue" with Finland regarding its alleged implementation deficiencies, in particular the exceptions it was making from the required strict protection of wolves (Hiedanpää and Bromley, 2011, p. 100). Unsatisfied with the response, in 2001 the Commission opened a formal infringement procedure against Finland (Hiedanpää and Bromley, 2011, p. 103). It argued that Finland's transposition of the Habitats Directive's language regarding the very limited situations in which strictly protected species could be legally killed was not sufficiently restrictive. For instance, where the Habitats Directive allows the possibility to kill a strictly protected animal when there is no other way to prevent "serious damage" to property [purpose (b)], or for "imperative reasons of overriding public interest" [purpose (c)], the Finnish regulations allowed for the killing of wolves to prevent "damage" to property or when it was in the "public interest." Beyond the 
linguistic problems, the Commission also criticized Finland for in fact granting permits to kill wolves in situations less restrictive than those allowed under the Habitats Directive.

Finland agreed that its regulatory language was not in compliance and, though continuing to classify wolves and some other Annex IV species as game animals, changed provisions in its hunting regulation relating to exceptions from strict protection to more closely adhere to the language of the Habitats Directive [Amendment to the Hunting Regulation of March 15, $2001(224 / 2001)$ at \$28]. However, it also continued to allow wolf hunting for purpose (b), to prevent serious damage, using arguably laxer standards than permissible, and in numbers estimated to be up to $25 \%$ of the population (Hiedanpää and Bromley, 2011, p. 103). Again unsatisfied with the limited steps toward compliance, the European Commission brought an infringement procedure against Finland in the CJEU for failing to meet its obligations under the Habitats Directive. In its 2007 judgment, the Court agreed that some of Finland's policies regarding the granting of wolf hunting permits did not comply with the Directive, in particular because permits were granted to kill wolves to prevent "serious damage" without an evaluation of the impact on wolves' conservation status, whether there were other solutions or even whether serious damage would actually be prevented (Case C-342/05, paras. 30, 31, 47).

During this infringement procedure and court case, the wolf population climbed despite the legal shortcomings of Finland's management, and was estimated to have reached 185-200 individuals at the time the case was brought to court (Case C$342 / 05$, para. 37). The wolf population reached 250 individuals in 2006, while the case was under consideration. That year, Finland started allowing so called management hunting, granting hunting licenses in areas with higher wolf populations for the stated purpose of preventing serious damage, purpose (b) under Article 16 of the Habitats Directive. During the winter 2006-2007 hunting season, 33 wolves were killed using management hunting permits and an additional five wolves were killed by police. In 2007, the year the decision was made, the wolf population fell back down to 200 post-hunt (Ministry of Agriculture and Forestry, 2015a,c).

Finnish Association for Nature Conservation's 1998 complaint to the European Commission eventually led to increased legal protection of wolves in Finland. After the Commission's legal action and CJEU decision, Finland enacted stricter legal protections for wolves. It stopped granting "management hunting" permits and established clearer guidelines for when wolves could be killed to prevent damage. This satisfied the European Commission, which closed its infringement proceeding (Borgström, 2012, p. 457-458). However, the wolf population continued to decline. In 2011, the Hunting Act was again amended to reflect stricter standards for granting permits, and criminal penalties for illegal killing were increased (Borgström, 2012). Despite these legal reforms, in 2013 the wolf population was back down to an estimated 120-135 individuals (Ministry of Agriculture and Forestry, 2015a). Finland conducted a review of its large carnivore policies that year, and began work on a new wolf management plan in 2014 .

\section{FINNISH WOLF LITIGATION ROUND 2: NGO TAPIOLA PROMPTS A REQUEST FOR A PRELIMINARY RULING}

\section{Participation in Public Hearings}

The Finnish Wildlife Agency and Natural Resources Institute Finland were tasked with preparing the new management plan under the authority of the Ministry of Agriculture and Forestry. There were a number of ways provided for the public to participate in the plan's preparation. Members of the public could contribute to an online discussion forum, and stakeholders in areas with wolf territories were invited to participate in regional workshops and other events in the fall of 2014 (Ministry of Agriculture and Forestry, 2015a). Stakeholders were selected by the Finnish Wildlife Agency, and included primarily representatives of hunting, agricultural, forestry, and dog owner associations, as well as representatives from the conservation group FANC, which had previously complained to the European Commission about Finland's noncompliance with the Habitats Directive, and the Finnish Nature League, FANC's youth association. At the regional meetings, representatives of the Finnish Wildlife Agency and Natural Resources Institute discussed with stakeholders the possibilities for achieving the favorable conservation status of the Finnish wolf while maximizing the participation of local stakeholders and minimizing negative impact on their livelihoods.

Leena Iivonen and Kantinkoski attended different regional workshops near their homes in the game management districts of North Häme and Satakunta, respectively. Iivonen had been invited as a local resident due to her participation in the online forum, and Kantinkoski as a representative of a local chapter of FANC. Potential methods for reducing damage discussed at the meetings they attended included providing financing for fencing or livestock guarding dogs, with hunting presented as a last resort when preventive measures failed. Reducing damage was considered to be important for increasing the public acceptance for wolves, and thereby reducing illegal killing. As 2014 drew to a close however, it became clear that hunting would be a goal of the new wolf policies rather than an emergency contingency measure. A draft version of the management plan was released that included a target of increasing the value of wolves as a game animal and a 2-year pilot program to reintroduce management hunting. The hunting season for 2015 would start already in January (Ministry of Agriculture and Forestry, 2014). The participation process and its result left both women feeling betrayed.

\section{An NGO Is Formed}

Access to public participation and access to information are well-established in Finland. Access to justice in environmental matters, on the other hand, has traditionally been more limited, but has expanded to comply with the Aarhus Convention and EU law. According to the 2000 Finnish Environmental Protection Act, associations with an environmental, health, or nature conservation purpose may generally bring public interest environmental litigation (Vanhala, 2018a, p. 386). Decisions 
to issue hunting permits, however, are made under hunting legislation and the procedural rules pertaining to environmental law do not apply. The Hunting Act (section 90) limits appeals of hunting permit decisions to only the permit applicant and to local and regional associations that have environmental or nature protection as their purpose. Individuals, national environmental organizations and even governmental actors have no ability to legally challenge the granting of hunting permits. If the granting of wolf hunting permits would be challenged in the Finnish courts, regional or local organizations would have to be the ones to do it.

Cognizant of this limitation, and that litigation would be the only way to stop the imminent hunting season, Iivonen called local chapters of FANC and other organizations in November of 2014 but found no enthusiasm for taking legal action. She then called Kantinkoski, with whom she had previously communicated on a Finnish wolf conservation Facebook group, and with whom she had subsequently tracked wolves near her rural home in central Finland, and Reija Laurila, another Facebook group participant. The three agreed to start an organization to protect wolves and other large carnivores. They paid the 60 euro required to register an organization with the Finnish Patent and Registration Office, ${ }^{3}$ and the regional Association for Nature Conservation Tapiola, covering all of Finland with exception of the reindeer management area and Åland, was born.

On the 22nd of January, 2015, the Ministry of Agriculture and Forestry and issued a decree setting the maximum number of management hunting permits that could be granted for the 2015 hunting season at 29 (Ministry of Agriculture and Forestry, 2015b). This time, according to the new management plan issued the same day, permits would be granted under purpose (e) of the Habitats Directive, which, as noted above, unlike purpose (b) did not specify a purpose, but rather allowed exceptions from strict protection to be made in very limited circumstances when there was no other satisfactory solution and doing so would not impact the conservation status of the populations of the species. The likelihood of preventing serious damage would thus no longer have to be demonstrated, as the CJEU had required when granting permits under purpose (b). Prospective hunters were to apply to the Finnish Wildlife Agency for a permit and provide some justification for wanting to hunt, but although the hunt was supposedly intended to remove problem wolves and reduce damage, the applicant did not need to provide any evidence of problems caused by wolves. It was recommended that hunters avoid killing "alpha" wolves, that is, members of the mating pair, and to attempt to target young wolves that were causing problems. However, there was no legal requirement to follow these recommendations. The hunting season would run from February 23 to March 15, 2015. Pursuant to the Ministry's decree, the Finnish Wildlife Agency granted 16 permits to kill a total of 24 wolves. Tapiola would appeal every permit.

\footnotetext{
${ }^{3}$ The cost of registering an organization is currently 100 euro. See https://www. prh.fi/en/yhdistysrekisteri/hinnasto/kasittelymaksut.html (last accessed April 30, 2020).
}

\section{Litigating the 2015 Hunting Season}

The permits had been granted in eight game management districts. The largest numbers of permits were granted in northern and eastern Finland; three permits to kill a total of four wolves were granted in the southwestern part of Finland and one permit to kill one wolf was granted in Northern Häme, a central region of Finland. Because the game management districts were within different administrative districts, Tapiola's appeals had to be filed in the Eastern Finland, Northern Finland, Turku, Vaasa, and Hämeenlinna administrative courts. Each permit had to be appealed separately, resulting in a total of 16 appeals.

Costs for administrative proceedings are relatively low in Finland compared to many countries (Vanhala, 2018a, p. 389390); no lawyer is required, and a fee, at the time 97 euro and currently 260 euro, has to be paid only if the complainant loses the case. Further, usually only written pleadings are required, saving the expense of preparing for a trial (Vanhala, 2018a, p. 389-390). However, the risk of losing 1552 euro if they lost sixteen appeals was not insubstantial, and Tapiola was not authorized to solicit charitable contributions. To raise the money, it sold a service-shares in the appeals. For six euro per share, purchasers could track their appeal in an online database. These shares offered individuals the opportunity to closely observe the legal attempt to save a wolf in the particular region in which a permit had been granted.

Iivonen prepared the appeals while Kantinkoski and others gathered data about the Finnish wolf's population size, structure and mortality, as well as on the authorities' actions to manage the wolf population. In their appeals, they argued that the precautionary principle had not been observed because the decision to hunt was based on a very uncertain prognosis of the size of the wolf population. Further, there was little evidence provided for the proposition that hunting would reduce conflicts or have a positive impact on the wolf population as claimed. They also argued that while the Habitats Directive allows exceptions from strict protection only in very limited circumstances when no other acceptable solutions could be found, Finland had not made a serious attempt to resolve problems without killing. Tapiola asked the court to issue an injunction against the permits, to rule that the permits had been illegally issued, and, because it believed that Finland was violating EU law, to ask the EU court for a preliminary ruling on how Article 16 of the Habitats Directive should be interpreted.

The courts in Eastern Finland, Northern Finland, and Vaasa rejected the requests for injunctions. These courts argued that the precautionary principle demanded that hunting should be allowed to continue, because hunting was intended to benefit the wolf population. If an injunction had been issued, the Eastern Finland Administrative Court for example argued, the hunt would not be able to continue, thus depriving the wolf population of the opportunity to be helped by being hunted. Injunctions were granted by the Hämeenlinna and Turku administrative courts.

All of the courts, except for Hämeenlinna, eventually dismissed the appeals on the grounds that Tapiola did not have standing. As noted above, only local and regional organizations have standing to appeal permit decisions. Tapiola was organized as a regional organization, and defined its regional space as 
encompassing about $2 / 3$ of the land area of Finland. Several courts, such as the Turku Administrative Court, dismissed the claims immediately because they considered that Tapiola's registered address was too far away from the game management district in which the appealed permit was granted for it to be considered sufficiently regional. Only the Hämeenlinna Administrative Court, which had responsibility for municipality of Mänttä-Vilppula where Tapiola had its registered address, found that Tapiola had standing. The court, however, rejected Tapiola's arguments, holding, as the government argued, that the hunt was an important experiment in wolf management that did not violate the Habitats Directive.

While the appeals all failed, three permits to kill a total of five wolves could not be used because the hunting season ended before their injunctions ran out. In its first year, Tapiola had prevented five wolves from being killed, and called attention to the possibility that, in not fully exploring other options to reduce damage to property and protect wolves, Finland may have been violating the Habitats Directive. Seventeen wolves were killed in the first hunting season.

\section{Litigating the 2016 Hunting Season}

The official estimate of the wolf population for 2015 was made in January, prior to hunting, as 220-245 individuals (Finnish Natural Resources Institute, 2015). This represented a historically large increase-close to two-fold-from the March 2014 estimate of 140-155 individuals. A prognosis based on number of wolf packs from Natural Resources Institute Finland claimed that there remained a similarly large number of wolves post hunt, in December of 2015. However, the population estimates had been based in a large part on observations by hunters during the winter, which would later be criticized in a 2016 evaluation commissioned by the Natural Resources Institute as resulting in "potentially rather imprecise population estimates, the accuracy of which is very difficult to estimate" (Andrén et al., 2016, p. 8). As the number of wolves permitted to be hunted was based partly on the population estimate, there was an incentive for those who hoped to hunt to report a high number of wolf observations. At any rate, as of late 2015, the early 2015 hunting season was considered a success.

On the 14th of December of 2015, the Ministry of Agriculture and Forestry issued its decree setting the number of wolves that could be hunted during the 2016 hunting season at 46 (Epstein and Chapron, 2018, p. 79). Four days later, the Finnish Wildlife Agency granted permission to kill all 46 possible wolves, distributed over 23 permits. The hunting season would run from January 23 to February 21, 2016. Hunters were again advised but not required to avoid killing members of the breeding pair and to attempt to target young wolves that had caused problems.

This time, the board of Tapiola did not intend to be dismissed for lack of standing. They quickly reorganized into six regional organizations covering the areas of Finland in which the permits had been granted, and appealed every permit. In their appeals, Tapiola again asked the administrative courts to issue an injunction against the permits, to declare that the granting of the permits violated the precautionary principle and EU law, and to ask the CJEU for a preliminary ruling on whether Finnish wolf management violated EU law. None of the appeals courts granted injunctions, and 44 out of the permitted 46 wolves were killed before the appeals were decided (Epstein and Chapron, 2018, p. 79). ${ }^{4}$

Tapiola fared better this time on the question of standing. In the majority of cases, the administrative courts found that its regional incarnations did have standing. However, all of the appeals in which Tapiola was determined to have standing were rejected on their merits. Several appeals were also rejected for lack of standing, including two in the Eastern Finland Administrative Court.

The Tapiola board was particularly surprised by these latter rejections. The same court had granted standing to a regional chapter of the Finnish Nature League 1 year earlier in similar circumstances. In that case, the court had maintained that while a regional organization could not achieve standing merely by defining itself as regional to a particular area in its bylaws, the Aarhus Convention and EU legal principle of effectiveness supported an expansive interpretation of organizational standing when questions of EU environmental law were at stake. In Tapiola's case, however, the court held that such an expansive interpretation was not necessary under EU law because other organizations existed that could potentially appeal the hunting permits, even though they had not chosen to.

The Tapiola board wanted to appeal every rejection to the Supreme Administrative Court, but was faced with a hard choice. The fee for losing an appeal to the Supreme Administrative Court had increased as of the first of January that year, from 250 to 500 euro. They did not know if they would be able to cover the potential losses. They decided to appeal just the two Eastern Finland decisions in which they were denied standing, because it seemed clear they had been treated differently than the Finnish Nature League.

By this point the Tapiola board was not sure that they could convince the Finnish authorities or courts that Finland was violating EU law, so they decided to also make a complaint to the European Commission, which they submitted in April 2016. While Finland claimed to be allowing hunting as a measure to improve the conservation status of wolves, the complaint argued, in reality Finland was not trying to improve the vitality of its wolf populations. Using the data that had been gathered, Tapiola demonstrated to the Commission that the non-lethal measures to reduce human-wildlife conflicts included in the management plans were greatly underutilized, whereas hunting and other lethal control was often the first choice rather than a last resort as claimed. Population monitoring was overly dependent on hunter observations, but available statistics showed no stable development of Finland's wolf population. Instead, the population had merely fluctuated within a relatively small range since 2000 .

As Tapiola informed the European Commission, if the goal of the management hunting experiment was to improve the conservation status of wolves, it had been a clear failure. The Finnish wildlife authorities had claimed that population

${ }^{4} 43$ wolves were killed during the hunt, and a 44th was wounded and later euthanized. 
models indicated about 30 wolves were being poached each year, thus necessitating legal hunting to reduce poaching. However, the 2016 hunting season permitted the hunting of 46 wolves, meaning that about 1.5 times as many wolves could be killed legally as had been suspected of being killed illegally (Epstein and Chapron, 2018, p. 85). This measure was clearly incapable of achieving its stated goal of reducing wolf mortality. Further, while hunters were requested not to kill breeding adult wolves, 20 out of the 44 individuals killed in the 2016 hunting season were breeding adults. The total human caused mortality in Finland that year, including kills in the reindeer management area, accidents, and removal by police order, was $78 .{ }^{5}$ The March 2017 population estimate showed that the wolf population had decreased to 150 170 individuals (Heikkinen et al., 2018, p. 7).

More than 1 year after Tapiola filed its appeals, in May of 2017, the Supreme Administrative Court overturned Eastern Finland's denial of standing (KHO:2017:T2492). Article 90 of Finland's Hunting Act did not require local or regional organizations to report particular activities in the area covered by the contested decision in order to have standing to appeal, the court noted, it only required that they have nature or environmental protection as a purpose. The court noted that in light of the CJEU's case law, this provision should not be interpreted restrictively because matters relating EU environmental law were at stake. But because the hunting season was over, the case would not be sent back to the Eastern Finland Administrative Court. Instead, the Supreme Administrative Court would consider the merits of Tapiola’s claims.

In November 2017, the Supreme Administrative Court made another decision (KHO:2017:182). It agreed with Tapiola that there were unclear questions of EU law that needed to be answered by the CJEU in order for it to determine whether Finland's hunting laws and policies violated the Habitats Directive. Although the 2016 hunt had long since been completed, the same management plan would continue to apply, so it continued to be relevant whether this plan was in line with EU law. The Supreme Administrative Court would therefore request a preliminary ruling on whether, and under what circumstances, hunting could be permitted based on purpose (e) of the Habitats Directive, whether hunting could be allowed because there was so satisfactory alternative way to prevent poaching, and how to interpret the requirement that exceptions to strict protection not be detrimental to the favorable conservation status of species' populations. Tapiola had succeeded in bringing its challenge to Finland's management hunting to the CJEU. Now that court would interpret several important questions pertaining to whether and when the Habitats Directive allowed the hunting of strictly protected species. The answer would apply throughout the EU.

\section{In the Court of Justice}

Shortly after their case was referred to the CJEU, the Tapiola board received two notifications. In early January 2018, they received a letter from the European Commission which informed

${ }^{5}$ Statistics obtained by requests to the Finnish Natural Resources Institute and Finnish Wildlife Agency. them it was closing its file on the complaint Tapiola had made because the case was now pending in the CJEU. This was the first communication Tapiola received from the Commission regarding its complaint. A second letter arrived in late January from the CJEU which informed them that as parties to the original proceeding, they had the right to submit written arguments to the Court, known as observations, on how they wanted the Court to interpret the questions put to it by the Finnish Supreme Administrative Court. These observations were due in 2 months.

The Tapiola board members were not knowledgeable about EU law or procedure, but they would work to acquire the needed expertise. This was their chance to convince the CJEU to put a stop to the wolf hunts that had led to the decline of the Finnish wolf population. Although there was a possibility to apply for funds to hire a lawyer, the board decided to write the observation themselves. They had each spent most of their time outside of work since 2014 researching Finnish wolves and their management, and did not believe there was a lawyer in Finland who could become as knowledgeable in the short time available to file the observation. They had by now filed more than 20 appeals and a complaint to the European Commission without an attorney, and would continue on their own.

Preparing to write the observation became like a second job, consuming every spare minute. They reread the European Commission's Guidance document on the strict protection of animal species of Community interest under the Habitats Directive $92 / 43 / E E C$ and analyzed how the guidelines and examples set out by the Commission might apply to the questions referred by the Finnish court. They reread the Advocate General's opinion and CJEU's decision in the 2007 Finnish Wolf Case, and the cases cited therein, and identified similarities in Finland's current wolf management with the management practices that had been criticized in that case. They read the Court's rules of procedure and practice directions, which were very different than the Finnish administrative courts'. They contacted academic researchers on wolf population dynamics and genetics for advice on scientific matters. Some academic researchers who had been studying the ongoing Finnish litigation, including Epstein, offered advice in formulating and formatting the observations. Finally, the Tapiola board mailed their analysis of the legal questions asked by the Finnish Supreme Administrative Court, with all of the evidence they had collected, to the CJEU. The package weighed $1 \mathrm{~kg}$ and $134 \mathrm{~g}$.

In early July, Tapiola received copies of other observations that had been submitted. They were gratified to see that the European Commission had also filed an observation that largely supported their positions. The Finnish Wildlife Agency and the Ministry of Agriculture and Forestry had filed observations defending the Finnish management hunt, and Denmark also filed an observation supporting hunting.

In late October, Tapiola received notification that the CJEU had decided to hold a hearing to receive further input on several additional questions related to the case. Parties to the original proceeding, as well as EU institutions and all EU Member States, 
had the right to give $15 \mathrm{~min}$ oral observations interpreting these questions or making other observations, as well as a $5 \mathrm{~min}$ rebuttal after the other observations had been made. The hearing would be held in early January.

The procedure in the Finnish administrative courts had been based on written pleadings only, so the Tapiola board members had no experience with oral arguments, but there was no question that they would participate. Preparation again consumed their lives. Iivonen and Kantinkoski read every case they could find on the Birds Directive and Habitats Directive that could be relevant to their arguments. They found a reasonably priced AirBnB in Luxemburg and formulated and practiced their arguments.

Oral hearings are open to the public, so Iivonen and Kantinkoski arrived in Luxemburg a day early to observe another hearing. The next day, they returned to the courtroom, donned the unfamiliar robes provided by the court, and gave their prepared statements. The Commission made oral observations that again largely supported Tapiola's positions, while the Finnish Wildlife Agency, Finnish Government and others made observations largely supportive of hunting. Then Iivonen and Kantinkoski made their rebuttals on behalf of Tapiola. They had done all they could to stop Finland from violating the Habitats Directive with respect to wolves.

\section{The Judgment of the CJEU}

The CJEU issued its judgment in October of 2019 (Case C674/17). As is so in preliminary rulings, the CJEU ruled on what would constitute a violation of EU law, but left the factual interpretation of whether the law had been violated to the national court. On several key points, however, the CJEU stated that if the Finnish court determined that the evidence provided by Tapiola or the Commission was accurate, it should find that Finland had violated the Habitats Directive.

According to the judgment, while in theory the prevention of poaching was an acceptable reason for derogating from the Habitats Directive's protections, and in theory the hunting of strictly protected species might be justified under purpose (e), the conditions for doing so are very demanding and did not appear to have been met in this case. First, national authorities must show, on the basis of "rigorous scientific data" that hunting to prevent poaching would have a "net positive effect" on the wolf population. Whether the national authorities had in fact met this burden, and whether in fact the derogation could achieve the aim of species protection was for the national court to "definitely establish," though the CJEU noted that from the submitted evidence, it appeared "doubtful." Second, derogation cannot be granted when other satisfactory alternatives are available; Member States must prioritize measures for preventing illegal killing that do not harm members of the species being protected, including "strict and effective monitoring of that illegal activity." National authorities granting hunting permits with a purpose of preventing poaching must provide a statement of reasons, having taken into account "the best relevant scientific and technical evidence" that establishes no "satisfactory alternative can achieve the objective pursued." In this case, the CJEU stated, it did not appear from the record that the Finnish authorities had met these requirements, though this also was for the national court to confirm.

The CJEU additionally addressed several important questions related to the requirement that derogation not be detrimental to the maintenance of the favorable conservation status of the populations of the species concerned. One important question was at what level conservation status should be considered. The CJEU noted that documents that had been submitted demonstrated that conservation status at the national level, and biogeographical level, was dependent on the cumulative impact of derogation at local levels. Therefore, an assessment the impact of the derogation on species populations at the local, as well as national and biogeographical levels was required. The CJEU noted that evidence presented by Tapiola and the Commission indicated that the contested permits and management hunting contributed a net negative impact on the Finnish wolf population, though that it was the role of the referring court to determine the accuracy of this evidence. Importantly, the CJEU ruled that the precautionary principle prevented Member States from allowing legal killing to combat illegal killing if "it is not guaranteed that the derogations will not be detrimental to the maintenance of the species populations concerned at a favorable conservation status," announcing a very high evidentiary burden which Finland had apparently failed to meet, though it was the role of the national court to make the ultimate determination.

The CJEU further interpreted the additional conditions related to purpose (e), that derogation must be limited as to the number of specimens taken, that taking must be on a selective basis and to a limited extent, and that derogation must be strictly supervised. Again, the CJEU required "rigorous scientific data" justifying the number of specimens taken. This case concerned permits allowing the taking of seven specimens, but, the CJEU held, this number "must be understood in the broader context" of the hunting program, which, it stated, resulted in the killing of " $15 \%$ of the entire wolf population of Finland, including numerous breeding specimens." The requirement for a selective basis and limited extent meant that the derogation should define the specimens to be taken "in the narrowest, most specific and efficient way possible," considering the derogation's purpose. The requirement for strict supervision meant that national legislation and authorities must guarantee that specimens of the species concerned were in fact taken on the selective basis and in the limited numbers allowed by the derogation. The CJEU noted that in this case, "the derogation permits merely recommended that the permit holders target certain individuals and avoid others, but does not oblige them to do so." The result, according to parties' documents, was that 20 alpha individuals were killed, against the permits' recommendations. The CJEU stated that, while it was for the referring court to check the accuracy of these reported facts, it did not appear that the contested permits complied with the requirements of purpose (e).

While the CJEU did not rule on factual issues, the judgment's implications were clear: Finland must improve protection for wolves. Further, because of the standards articulated in this judgment, it will be more difficult to authorize the killing of any animal protected by EU law throughout the EU. 


\section{The Judgment of the Finnish Supreme Administrative Court}

The Finnish Supreme Administrative Court's judgments on the legality of the two appealed permits came at the end of March, 2020 (KHO 2020:27; KHO 2020:28). After the CJEU's decision, Tapiola's victory was all but ensured. The court ruled that the management hunting permits granted during the 2016 hunting season violated Finnish hunting law, which had to be understood in light of the provisions of the Habitats Directive that it implemented, and the CJEU's decision. First, the Finnish Wildlife Agency had not demonstrated, on the basis of scientific data, that hunting could achieve the goal of reducing illegal killing or that it would have a net positive impact on the population. The information provided by the Agency on poaching was limited and uncertain. While the management plan contained an estimate, based on population modeling, of how many wolves might have been poached, the Agency had not even attempted to assess the impact the hunting permits would have on poaching in the regions in which the permits were granted. Further, the Agency had not demonstrated a lack of satisfactory alternatives. The management plan included a number of other measures for reducing illegal killing, such as increasing public information about wolves and increased monitoring. The Agency had not put forward any explanation of why these other measures were not satisfactory. Further the Agency had not guaranteed that the unfavorable conservation status of affected wolf populations would not be worsened at the local, biogeographical or national level. It had granted permits allowing the killing of about $1 / 3$ of the wolves in the local areas affected. These decisions did not contain assurances as to why the unfavorable conservation status of Finnish or regional wolf populations would not be worsened. Lastly, while the permits delimited the time, place, and number of wolves that could be killed, the court ruled that these restrictions were not sufficient to meet the requirement that derogation under purpose (e) occur "under strictly supervised conditions, on a selective basis and to a limited extent." Mere recommendations that hunters avoid targeting the alpha pair were insufficient, especially when such a large percentage of the local population could be killed. Tapiola had won its case.

\section{DISCUSSION}

Tapiola's arguments prevailed on several important points in the CJEU, and it consequently won its appeals of the hunting permits that had been granted by the Finnish Wildlife Agency. But however the CJEU had ruled, the case would have been a success from an EU standpoint. A committed group of stakeholdersin this case individuals who desire wolf conservation-had used substantive and procedural EU laws to bring about the uniform interpretation of EU law and promote its enforcement in a Member State.

The effectiveness of EU law is in a large part dependent on citizen enforcement, as the EU does not have the administrative apparatus to detect and litigate more than a small percentage of violations (Kelemen, 2011; Hofmann, 2019). This has been increasingly true in the area of environmental law, as Member
States have been forced to expand the ability of interest groups to bring cases in national courts in order to comply with the Aarhus Convention and the EU legal principle of effectiveness (Epstein, 2018; Hellner, 2019). While Western European countries like Finland signed Aarhus believing that it would primarily impact democratically deficient former Soviet countries and not their own legal systems (Vanhala, 2018b, p. 116), Tapiola’s success in gaining standing to appeal Finnish management hunting is one of several examples illustrating the impact this agreement and its EU implementation have had in shaping procedural law throughout Europe and opening up the national courts to environmental claims. As argued by Hofmann, all Member State legal systems have had to make some level of changes to comply (Hofmann, 2019 , p. 353). Procedural environmental rights were not an issue before the CJEU in the Tapiola case because the Finnish Supreme Administrative Court had already considered CJEU's earlier decisions and therefore did not question whether Tapiola should be granted standing.

Tapiola's story nevertheless illustrates the power of procedural environmental rights. The Tapiola board utilized every pillar of the Aarhus Convention: They participated in the public hearings that led up to the development of the wolf management plan. When they perceived that their participation as stakeholders was not meaningful, they formed an organization and accessed the courts to try to enforce EU law. ${ }^{6}$ They requested information about hunting permits granted and wolves killed from the Finnish authorities, which they used to demonstrate the merits of their case in the Finnish and EU courts, and to inform the European Commission of potential inadequacies in Finland's wolf management. They were able to have their claims examined at the highest level of Finland's judicial system as well as at the highest level of the EU judicial system.

The Tapiola case, though successful, also demonstrates some shortcomings in relying on public interest organizations to bring about compliance with EU environmental law. As pointed to by Hofmann, there are violations of EU environmental law that no NGO chooses to pursue (Hofmann, 2019, p. 358). Wolves are a charismatic species, but still the existing Finnish NGOs made only limited attempts to enforce EU laws for their protection. In this instance, there happened to be several committed individuals who formed a new organization to fill the enforcement gap, but other equally important violations likely remain unnoticed. Second, the group of individuals had to be sufficiently committed to spend years essentially working a second job without pay. Even in Finland, where the financial barriers to bringing administrative claims are relatively low (Vanhala, 2018a, p. 389-90), the investment of time and financial risk required is likely a barrier to bringing many legitimate claims.

Successful decentralized enforcement is also, as noted by Eliantonio, dependent on the cooperation of the national courts (Eliantonio, 2018, p. 759). The lower administrative courts all rejected either Tapiola's standing claim, which was in part based on EU procedural law, or its substantive claims based on the

\footnotetext{
${ }^{6}$ Lisa Vanhala has observed that "perceived exclusion from political decision
} making" is often the impetus for NGO litigation (Vanhala, 2018a, p. 401-402). 
Habitats Directive. If the Finnish Supreme Administrative Court had not agreed that these claims based in EU law had sufficient merit to grant standing and refer the case to the CJEU, Tapiola would have had no recourse but to hope the European Commission would intervene. The Finnish courts are relatively open to EU law and refer a handful of cases each year, but some countries almost never do (Court of Justice of the European Union, 2019, p. 125).

There is another important difference in the type of judgment the CJEU makes when deciding an infringement case brought against a Member State by the European Commission and when deciding a preliminary ruling referred by a Member State court. In the former, the CJEU rules on whether the Member State has fulfilled its obligations under EU law. In the 2007 Finnish Wolf Case, brought by the European Commission after a complaint from an NGO, the court examined Finland's decisions to allow the killing of wolves under the exception in the Habitats Directive's purpose (b), the prevention of serious damage, and ruled that Finland had violated the Habitats Directive because it had not demonstrated serious damage was likely to be prevented. The broader meaning of that decision and in what other types of situation it should apply would continue to be debated, but Finland was clearly told that it was currently violating the Habitats Directive and had to change its management practices.

When a Member State brings a reference for a preliminary ruling, however, the CJEU does not necessarily examine evidence as to whether the law is currently being violated. Instead, it interprets the question of EU law put before it by the Member State court, and returns the case for the Member State to apply the law to the evidence. In the Tapiola Case, the CJEU did not rule on whether Finland has violated in the Habitats Directive. Instead, it told the Finnish Supreme Administrative Court that if it found Finland had not met certain requirements, it should find that Finland had violated the Habitats Directive. Although in this case it was clear how the Finnish court should rule assuming the evidence was accurate, other decisions may leave more room for interpretation

\section{REFERENCES}

Andrén, H., Mönkkönen, M., and Ovaskainen, O. (2016). An Evaluation of the Scientific Quality of Finnish Wolf Population Monitoring. Available online at: https://www.luke.fi/wp-content/uploads/2016/10/Wolf_report_final_version. pdf (accessed April 30, 2020).

Aspi, J., Roininen, E., Ruokonen, M., Kojola, I., and Vila, C. (2006). Genetic diversity, population structure, effective population size and demographic history of the Finnish wolf population. Mol. Ecol. 15, 1561-1576. doi: 10.1111/ j.1365-294X.2006.02877.x

Bisi, J., and Kurki, S. (2008). The Wolf Debate in Finland. Available online at: http://hdl.handle.net/10138/17925 (accessed April 30, 2020).

Borgström, S. (2012). Legitimacy issues in Finnish wolf conservation. J. Environ. Law 24, 451-476. doi: 10.1093/jel/eqs015

Chapron, G., Epstein, Y., Trouwborst, A., and López-Bao, J. V. (2017). Bolster legal boundaries to stay within planetary boundaries. Nat. Ecol. Evol. 1:0086. doi: 10.1038/s41559-017-0086

Court of Justice of the European Union (2019). Annual Report 2018 Judicial Activity. Available obline at: https://curia.europa.eu/jcms/upload/docs/ application/pdf/2019-04/_ra_2018_en.pdf (accessed April 30, 2020). for the Member State court to determine whether EU law has been violated.

The Aarhus Convention and EU provide the procedural and substantive legal tools for stakeholders to access national courts to protect biodiversity and the environment. Using these tools requires time, money and perseverance, but can lead to better enforcement of environmental laws. The level of engagement with EU law by Member State courts will also impact whether decentralized enforcement is effective. Public interest litigation can complement but not substitute for centralized enforcement of EU law by the European Commission, which also requires an engaged public.

\section{DATA AVAILABILITY STATEMENT}

The original contributions presented in the study are included in the article, further inquiries can be directed to the corresponding author.

\section{ETHICS STATEMENT}

Written informed consent was obtained from the individual(s) for the publication of any potentially identifiable images or data included in this manuscript.

\section{AUTHOR CONTRIBUTIONS}

All authors listed have made a substantial, direct and intellectual contribution to the work, and approved it for publication.

\section{FUNDING}

YE gratefully acknowledges research funding from Riksbankens Jubileumsfond for project P18-0599:1.

Eliantonio, M. (2018). The role of NGOs in environmental implementation conflicts: 'Stuck in the middle' between infringement proceedings and preliminary rulings? J. Eur. Integr. 40, 753-767. doi: 10.1080/07036337.2018. 1500566

Epstein, Y. (2018). Adversarial legalism and biodiversity protection in the United States and the European Union. Transl. Environ. Law 7, 491-513. doi: $10.1017 /$ S2047102518000109

Epstein, Y., and Chapron, G. (2018). The hunting of strictly protected species: the Tapiola case and the limits of derogation under article 16 of the habitats directive. Eur. Ener. Environ. Law Rev. 27, 78-87.

Epstein, Y., and Darpö, J. (2013). The wild has no words: environmental NGOs empowered to speak for protected species as Swedish courts apply EU and international environmental law. J. Eur. Environ. Plan. Law 10, 250-261.

Ermala, A. (2003). A survey of large predators in Finland during the 19th20th centuries. Acta Zool. Litu. 13, 15-20. doi: 10.1080/13921657.2003.1051 2538

European Commission (2017). Communication from the Commission: EU Law: Better Results through Better Application (2017/C 18/02). Available online at: https://eur-lex.europa.eu/legal-content/EN/TXT/?toc=OJ\%3AC\%3A2017\% 3A018\%3ATOC\&uri=uriserv\%3AOJ.C_.2017.018.01.0010.01.ENG 
Finnish Natural Resources Institute, (2015). Lausunto talven 2014-2015 susitilanteesta (Estimate of the wolf population winter 2014-2015. Helsinki: Finnish Natural Resources Institute.

Gellers, J. C., and Jeffords, C. (2018). Toward environmental democracy? Procedural environmental rights and environmental justice. Glob. Environ. Polit. 18, 99-121. doi: 10.1162/GLEP_a_00445

Heikkinen, S., Kojola, I., Mäntyniemi, S., Holmala, K., and Härkälä, A. (2019). Vargstammen $i$ Finland $i$ mars 2019 (The Wolf Population in Finland in March 2019). Available online at: https://jukuri.luke.fi/handle/10024/544159 (accessed April 30, 2020).

Heikkinen, S., Kojola, I., Mäntyniemi, S., and Holmala, K. (2018). Susikanta Suomessa Maaliskuussa 2018 (The Wolf Polulation in Finland in March 2018): Luonnonvara- ja biotalouden tutkimus 27/2018. Luonnonvarakeskus. Available online at: https://jukuri.luke.fi/handle/10024/542057 (accessed April 30, 2020).

Hellner, A. (2019). Arguments for Access to Justice: Supra-individual Environmental Claims Before Administrative Courts. Doctoral Thesis, Uppsala University, Sweden.

Hiedanpää, J. (2013). Institutional misfits: law and habits in Finnish wolf policy. Ecol. Sci. 18:24. doi: 10.5751/ES-05302-180124

Hiedanpää, J., and Bromley, D. W. (2011). The harmonization game: reasons and rules in European biodiversity policy. Environ. Policy Gov. 21, 99-111. doi: 10.1002/eet.561

Hofmann, A. (2019). Left to interest groups? On the prospects for enforcing environmental law in the European Union. Environ. Polit. 28, 342-364. doi: 10.1080/09644016.2019.1549778

Kelemen, R. D. (2011). Eurolegalism: The Transformation of Law and Regulation in the European Union. Cambridge, MA: Harvard University Press.

Kojola, I., Helle, P., Heikkinen, S., Lindén, H., Paasivaara, A., and Wikman, M. (2014). Tracks in snow and population size estimation: the wolf Canis lupus in Finland. Wildl. Biol. 20, 279-285. doi: 10.2981/wlb.00042

Kramer, L. (2014). EU enforcement of environmental laws: from great principles to daily practice-improving citizen involvement. Environ. Policy Law 44, 247-256.

Linnell, J. D. C., Solberg, E. J., Brainerd, S., Liberg, O., Sand, H., Wabakken, P., et al. (2003). Is the fear of wolves justified? A Fennoscandian perspective. Acta Zool. Litu. 13, 34-40. doi: 10.1080/13921657.2003.10512541

Ministry of Agriculture and Forestry (2005). Management Plan for the Wolf Population in Finland. Helsinki: Ministry of Agriculture and Forestry.

Ministry of Agriculture and Forestry (2014). Memorandum on a Decree to Allow Hunting Outside the Reindeer Management Area 2014-2015. Helsinki: Ministry of Agriculture and Forestry.

Ministry of Agriculture and Forestry (2015a). Management Plan for the Wolf Population in Finland. Helsinki: Ministry of Agriculture and Forestry.

Ministry of Agriculture and Forestry (2015b). Decree on Hunting of Wolves by Means of Dispensation outside the Reindeer Management Area During the Hunting Year 2014-2015. Helsinki: Ministry of Agriculture and Forestry.

Ministry of Agriculture and Forestry (2015c). Ministry of Agriculture and Forestry of Finland: Background of the Management Plan for Wolves 2015, Status and
Development of Wolf Population in Finland, 2015, eds I. Kojola, and S. Kaartinen 5-6, Available online at: https://riista.fi/wp-content/uploads/2018/06/Suomensusikannan-hoitosuunnitelma-taustaosio.pdf (accesssed April 30, 2020).

Ministry of Agriculture and Forestry (2016). Evaluation of the Management Hunting Trial and Recommendation for Next Steps (Suden Kannanhoidollisen Metsästyksen Kokeilun Arviointi Ja Suositukset Jatkotoimenpiteistä). Helsinki: Ministry of Agriculture and Forestry.

Mykrä, S., Vuorisalo, T., and Pohja-Mykrä, M. (2005). A history of organized persecution and conservation of wildlife: species categorizations in Finnish legislation from medieval times to 1923. Oryx 39, 275-283. doi: 10.1017/ S0030605305000797

Pohja-Mykrä, M. (2016). Felony or act of justice?-Illegal killing of large carnivores as defiance of authorities. J. Rural Stud. 44, 46-54. doi: 10.1016/j.jrurstud.2016. 01.003

Pohja-Mykrä, M., and Kurki, S. (2014). Evaluation of the Finnish National Policy on Large Carnivores. Available online at: https://helda.helsinki.fi/handle/10138/ 229365 (accessed April 30, 2020).

Reichel, J. (2010). Judicial control in a globalised legal order-a one way track? An analysis of the case C-263/08 djurgården-lilla värtan. Rev. Eur. Adm. Law 3, 69-87. doi: 10.7590/REAL_2010_02_05

Trouwborst, A., Blackmore, A., Boitani, L., Bowman, M., Caddell, R., Chapron, G., et al. (2017). International wildlife law: understanding and enhancing its role in conservation. BioScience 67, 784-790. doi: 10.1093/biosci/bix086

Trouwborst, A., and Fleurke, F. M. (2019). Killing wolves legally: exploring the scope for lethal wolf management under European nature conservation law. J. Int. Wildl. Law Policy 22, 231-273. doi: 10.1080/13880292.2019.168 6223

Vanhala, L. (2018a). Is legal mobilization for the birds? Legal opportunity structures and environmental nongovernmental organizations in the United Kingdom, France, Finland, and Italy. Comp. Polit. Stud. 51, 380-412. doi: 10.1177/ 0010414017710257

Vanhala, L. (2018b). Shaping the structure of legal opportunities: Environmental NGOs bringing international environmental procedural rights back home. Law Policy 40, 110-127. doi: 10.1111/lapo.12093

Conflict of Interest: The authors declare that the research was conducted in the absence of any commercial or financial relationships that could be construed as a potential conflict of interest.

The handling editor declared a past co-authorship with one of the authors, YE.

Copyright (c) 2020 Epstein and Kantinkoski. This is an open-access article distributed under the terms of the Creative Commons Attribution License (CC BY). The use, distribution or reproduction in other forums is permitted, provided the original author(s) and the copyright owner(s) are credited and that the original publication in this journal is cited, in accordance with accepted academic practice. No use, distribution or reproduction is permitted which does not comply with these terms. 